\title{
INTEGRATED PRODUCT POLICY AND ECOLOGICAL FOOTPRINT OF ELECTRONIC PRODUCTS
}

\author{
S.D. Frey, Dr. D. J. Harrison, Prof. E. H Billett \\ Brunel University, Cleaner Electronics Research Group, Runnymede Campus, Egham, UK \\ Sibylle.Frey@Brunel.ac.uk
}

\begin{abstract}
Introduction
Integrated Product Policy (IPP) is a relatively new field in environmental policy developed to contribute to sustainable development as defined in the Brundtland-Report [1]. As such, its global objective is to improve resource efficiency and the environmental impact from the consumption of goods and services [2] and to 'green' the marketplace through the supply and demand chain $[4,3]$. The concept of IPP differs from the conventional approach in that it covers all product systems and their environmental effects by pursuing a life-cycle (LC)-thinking, thus avoiding shifting environmental problems between different stages of the life cycle. Within IPP, all existing management and regulation tools will still be valid but their use might be reassessed within a new framework in which all stakeholders are incorporated and new instruments may be developed [1]. Five IPP measures have been identified: 1. Measures aimed at reducing and managing wastes generated through the consumption of products 2 . Encouragement for the innovation of more environmentally sound products 3. Creating markets for those products 4. Transmission of information along the product chain 5: Allocation of product responsibility for environmental burdens [2]. IPP will therefore encourage changes in behaviour within all stakeholders [1].
\end{abstract}

However, there are many challenges and questions which have to be solved in implementing IPP. These are seen, for example, in the co-operation of different stakeholders, in the key focus on products, in what tools there are to reveal the link between a product and its environmental impact, and in balancing market forces and sustainable development [1]. But there is still some confusion about what IPP could be and how the impact of such an approach would look like - for example when moving away from a product-focused towards a service-focused industry. The European Commission (EC) is going to address the main issues and problems by further research based on joint pilot projects within stakeholders [1].

The Ecological Footprint (EF) methodology, developed by Wackernagel and Rees, is already a very effective sustainability indicator for the human impact on earth. EF are calculated by dividing the biologically productive land and sea space of the earth by its population. Thus, EF can be established on a global or other geographic level. In this paper, we discuss whether the EF can be brought down to a product level to assess the sustainability of a Personal Computer (PC). We also used land-space as a single indicator to make results comparable to the current world-average footprint. Recent work in this sector has been done by Buitenkamp and Spapens [5]. This paper extends their research.

\section{Background}

The key question behind the EF is whether naturesí productivity is sufficient to satisfy present and future demands of the economy indefinitely. The EF method assumes that every category of energy and material consumption and waste requires the productive or absorptive capacity of a finite area of land or water [6]. EFs sum up the biologically productive areas of consumption and waste where ever that land or water may be located on the planet [9 Previous studies based on United Nations statistics have shown that man's use of natural resources exceeds the earth's carrying capacity by more than a third [8].
If global biologically productive sea and land space on earth are divided by the global population, the average space per capita is 2.2 hectares (ha) per person. Without the sea, average land space is around 1.7 ha per capita [8]. The Brundtland Commission suggested a figure of 12 per cent for the other 10 to 30 million species on the planet, which might be politically feasible but will probably not be enough for securing long-term biodiversity [9]. From this, approximately 1.5 hectares per capita are left [7]. With an anticipated number of ten billion people by 2050 , the available space will be reduced to 1.2 hectares world wide, including the productive areas of the seas [7]. These figures are likely to be underestimated as to date, apart from $\mathrm{CO}_{2}$, other emissions, toxins and wastes are not included in the calculations [6]. 


\section{Experiments}

\section{A. Methodology resource consumption:}

The data for this footprint analysis was taken from a LCA report on a generic PC from 1998 [10], carried out on behalf of the EC. The equipment was based on the following assumptions:

\begin{tabular}{|c|c|}
\hline $200 \mathrm{MHz}$ CPU and cooler & Power supply \\
\hline 16MB EDO RAM & Mini tower cabinet \\
\hline 4 MB RAM graphics adapter & CD-ROM drive \\
\hline 3 GB IDE hard disk & $15 \hat{~ S V G A ~ c o l o u r ~ m o n i t o r ~}$ \\
\hline $3.5 \hat{~}$ floppy drive & Keyboard and mouse \\
\hline $\begin{array}{l}\text { Power consumption Monitor } \\
\text { and Control Unit . (incl. } \\
\text { Keyboard) }\end{array}$ & 100 and 60 Watts \\
\hline Lifetime & $\begin{array}{l}3 \text { years (230 days or } 5520 \\
\text { hours) }\end{array}$ \\
\hline $\begin{array}{l}\text { Transport distance truck / } \\
\text { van }\end{array}$ & $525 \mathrm{~km}$ \\
\hline Disposal routes Europe & $\begin{array}{l}63 \% \text { landfilled, } 22 \% \\
\text { incineration with } 75 \% \text { heat } \\
\text { recovery, } 15 \% \text { recycling }\end{array}$ \\
\hline Recovery rates metals & $\begin{array}{l}\text { Steel } 97 \% \text {, Alu } 95 \% \text {, other } \\
100 \%\end{array}$ \\
\hline
\end{tabular}

Tab. 1. Generic PC data according to [10]

The impact assessment data was used for translating primary energy consumption into land space. The direct land-use data for the LCI materials was calculated from Frischknecht [11], which is mostly site-specific. Using the direct consumption of land space takes into account that even with recultivation measures after mining operations, the original environment with its species and habitats cannot be re-installed [12].

The separate LCI inputs were appropriated to land areas. No generic information is available with regard to the land affected through mining operations, as they differ between sites. Where possible, overburden were included and added to the extraction data. Overburden data was collected from Douglas and Lawson [13], Schmidt-Bleek [14] and Frischknecht [11]. In our calculations the higher overburden values were used as they were sometimes given as an ore to commodity ratio, or included all material movements associated with extraction. An example is given in table 2 .

\begin{tabular}{|l|l|l|l|}
\hline Material: & $\begin{array}{l}\text { Aluminiu } \\
\mathrm{m}\end{array}$ & Copper & Hardcoal \\
\hline $\begin{array}{l}\text { Land use } \\
\left(\mathrm{m}^{2} / \mathrm{kg}\right)\end{array}$ & $5.49 \mathrm{E}-04^{\mathrm{a}}$ & $6.41 \mathrm{E}-04^{\mathrm{a}}$ & $1.80 \mathrm{E}-04^{\mathrm{a}}$ \\
\hline $\begin{array}{l}\text { Overburde } \\
\text { n factor: }\end{array}$ & $3.68^{\mathrm{b}}$ & $450^{\mathrm{c}}$ & $4.87^{\mathrm{c}}$ \\
\hline \multicolumn{2}{|l|}{ Calculated from FK $1996 ;^{6} \mathrm{FK} 1996 ;^{\mathrm{c}} \mathrm{DL} 1998$} \\
\hline
\end{tabular}

Tab. 2. Example commodities and their overburden.
For some raw materials the land space required for processing steps after the extraction phase could be included, such as for oil, coal, and natural gas. For gas and oil pipelines, space for infrastructure could not be established due to lack of data. The embedded energy was included in the LCA for all LCI inputs (IPU, pers. comm.). Some metals where found not to be included in the LCI, such as some Gold $(0.8 \mathrm{~g})$, Silver $(0.97 \mathrm{~g})$, Beryllium $(0.13 \mathrm{~g})$ and some Cadmium. Water was not included in this EF assessment. Therefore, land for resource consumption is believed to be highly underestimated.

\section{B. Methodology for carbon dioxide emissions}

Fossil-energy-land is the land to be reserved for $\mathrm{CO}_{2}$ absorption and refers to the spatial impact of fossil fuel use. As a minimum requirement, the fossil carbon added to the carbon cycle of the biosphere through burning must be sequestered. Today, the only sequestering technique applied is growing forest that will not be harvested. Such land serves as a carbon dioxide sink during a period of 40 to 100 years, depending on climate and tree species. In order not to release the fixed $\mathrm{CO}_{2}$, the mature forest would have to be left for the future without human intervention, spontaneously renewing itself. Harvesting is only possible with little wastage and if most of the biomass is transformed in long-lasting products [16].To avoid increasing levels of $\mathrm{CO}_{2}$ in the atmosphere in case of continued fossil fuel use, additional areas would have to be set aside for sequestration. This is not included in the calculations [7]. Here, a world average carbon absorption of 1.42 tonnes per hectare and year including root mass, is applied, based on FAO data [7]. The latest data from the Intergovernmental Panel on Climate Change [15, 16] have been used to calculate the fossil fuel specific carbon uptake by forests. As oceans are a major sink for $\mathrm{CO}_{2}$, they have been included in the calculations. However, data for the amount of anthropogenic carbon which is fixed by the sea is based on complex models which can vary significantly. The Hadley Centre assumes a figure of 25 to 33 per cent for anthropogenic carbon dioxide uptake by oceans (Hadley Centre, pers. comm.,) which is in line with the literature. However, should the oceans warm substantially, an opposite effect may counterbalance this absorption to some extent because warming water emits $\mathrm{CO}_{2}$ into the air [17]. Here we used an absorption rate of 25 per cent of $\mathrm{CO}_{2}$ per year. Table 3 gives an overview on carbon absorption by forests. 


\begin{tabular}{|c|c|c|c|c|c|}
\hline \multicolumn{5}{|c|}{$\begin{array}{l}\text { World ave rage car bon ab sor ption by fo rest s: } \\
1.42 \text { tonnes of carbon [tha/yy] including roots (Wac at al. 1999) }\end{array}$} & \multirow[b]{2}{*}{ W per $\mathrm{m}^{2}$} \\
\hline & - CEF [t Cl TJ] & Gl/ha/ yr & $M J / m^{2} / y_{r}$ & bNCV & \\
\hline Crude oil & 20 & 71 & 7.10 & 67 & 6.75 \\
\hline Coal & 26 & 55 & 5.50 & 52 & 5.23 \\
\hline Nat.gas & 15.3 & 93 & 9.30 & 84 & 8.37 \\
\hline \multicolumn{5}{|c|}{ - Cabon enission factors (PCC 1997 a) } & \\
\hline \multicolumn{6}{|c|}{ - Net Calorific Vatues for tossi fues: $95 \%$ of liquid and solid tossï and tiomass fuels. } \\
\hline \multicolumn{2}{|c|}{$90 \%$ of naural gas (IPCC11997 a) } & & & & \\
\hline
\end{tabular}

Tab. 3. Fuel specific carbon absorption by forests.

\section{Results and Discussion:}

\section{A. Resource consumption-land}

\section{Land-space of resource consumption by PC system:}

By comparing the LCA amounts of resources with their respective land use, quantities and land-space do not change proportionally as overburdens are included for "non-renewables". This is especially visible in the case of copper with an overburden of $450 \mathrm{~kg}$ per $\mathrm{kg}$ copper derived from surface mining. Biomass was calculated as wood with a growth of $0.5 \mathrm{~kg}$ dry matter per $\mathrm{m}^{2} /$ year $[15,16]$. The primary reason fossil fuels absorb so much space is related to the very high amount consuined. In the case of the keyboard, the relative high amounts of the raw materials crude oil and natural gas are due to the plastic ABS. The metals to plastic ratio is higher in the Monitor and Control Unit, which explains their higher presence in the land use data. Tabie 4 shows the hierarchy for the top four resources from both studies.

\section{Land-space of resource consumption by life cycle}

Fig. 1 shows the results for Monitor, Control Unit and Keyboard. For all three PC systems the material production determines the footprint-size with 53,71 and 93 per cent. The use phase follows with 44 and 22 per cent of land consumption. Between 3 and 8 per cent of land-space are credited for recycling, which is 6 to 12 per cent of the space for material production. Land-space for material production was mainly determined by copper extraction, whereas fossil fuels determined the use phase.

It should be mentioned here that the credited land space is rather to be interpreted as space saved from further material extraction due to recycling, and not as a reconstitution of the original environment. Even if the environmental "rucksacks" are put back into the hole they have been taken from, they alter the sustainability of the area affected as they affect future erosion and slope stability of the respective site [13]

\begin{tabular}{|l|l|l|}
\hline Monitor & LCA results & Land-use results \\
& 1. Hard coal, fuel & 1. Crude oil, fuel \\
& 2. Lignite, fuel & 2. Copper \\
& 3. Natural gas, fuel & 3. Hard coal, fuel \\
4. Crude oil, fuel & 4. Lignite, fuel \\
\hline Control Unit & 1. Hard coal, fuel & 1. Unspecified bm f \\
& 2. Lignite, fuel & 2. Copper \\
& 3. Crude oil, fuel & 3. Crude oil, fuel \\
& 4. Natural gas, fuel & 4. Wood, fuel \\
\hline Keyboard & 1. Hard coal, fuel & 1. Copper \\
& 2. Crude oil & 2. Wood, fuel \\
& 3. Crude oil raw & 3. Crude oil, fuel \\
& mat Natural gas, raw & 4. Crude oil, raw \\
& material & material \\
\hline
\end{tabular}

Tab. 4. Hierarchy of resources LCA and land-use.

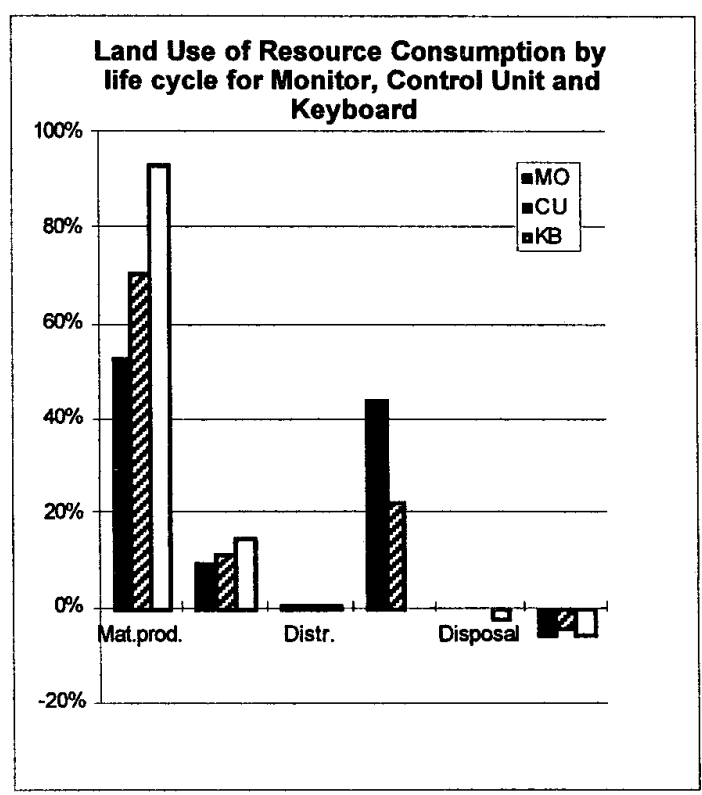

Fig. 1. Land use of resource consumption

\section{B. Fossil-Energy-Land}

1. Land-space for energy from materials by life cycle

As the results reflect the primary energy values from the LCA given in Mega Joules, the required land space for $\mathrm{CO}_{2}$ sequestration is allocated pro rata.

If the primary energy for materials is appropriated into land space, the material production phase requires about $26 \mathrm{~m}^{2}$, or more than 99 per cent of land-space in the Monitor, Control Unit and Keyboard. This reflects the relatively energy costs in the extraction of non-renewable resources including 
the removal of overburden. However, land for material energy only accounts for 1.5 per cent of the land for process energy.

\section{Land-space for energy from processes by life cycle}

Regarding process energy, the land-use is highest in the use phase for Monitor and Control Unit - it takes up $1340 \mathrm{~m}^{2}$ (80 or 72 per cent). Manufacturing comes second with $340 \mathrm{~m}^{2}$ (18 and 21 per cent for Monitor and Control Unit, 49 per cent for the Keyboard. Material production uses about $88 \mathrm{~m}^{2}$ (3,7 and 56 per cent). Around $9 \mathrm{~m}^{2}$ credit are credited for recycling, which is 7,12 and 3 per cent of material production respectively.

Overall, the use phase consumes the lion's share of land-space for absorbing $\mathrm{CO}_{2}$ emissions from material and process energy. Manufacturing consumes 25 per cent, and material production only 9 per cent of the land-space consumed for the use phase. Thus, the Monitor has the largest energy-footprint from using and manufacturing it $\left(1070 \mathrm{~m}^{2}\right)$. The Control Unit holds the second place with $703 \mathrm{~m}^{2}$, and the Keyboard has the smallest energy-footprint $\left(15 \mathrm{~m}^{2}\right)$ from material production and manufacture. Including resource consumption, the EF of the total $\mathrm{PC}$ is 1790 $\mathrm{m}^{2}$, or 0.18 ha. If 25 per cent of anthropogenic $\mathrm{CO}_{2}$ emissions are absorbed by oceans, the PC's footprint on earth is still $1342 \mathrm{~m}^{2}(0.13 \mathrm{ha})$. Figures 2 and 3 show the energy footprints, and the results are summarised in table 5 .

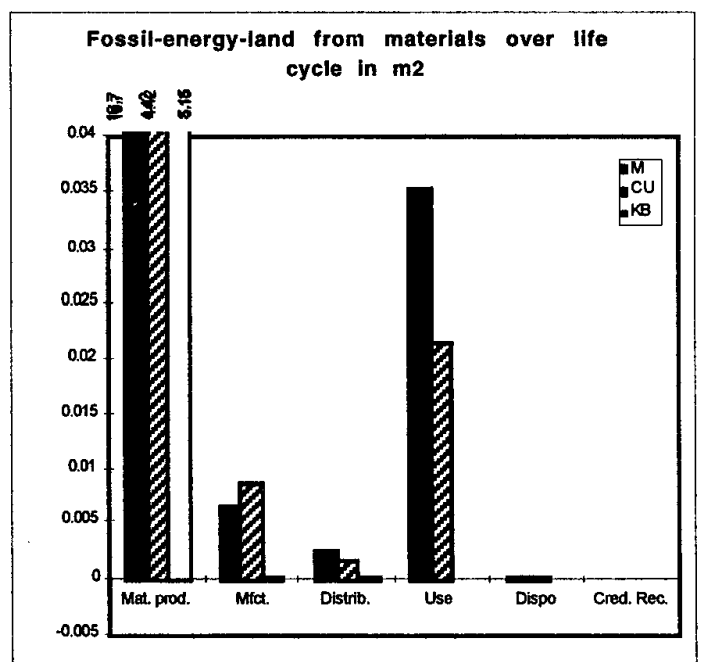

Fig. 2. Land-space from materials energy.

\begin{tabular}{|l|l|l|l|}
\hline Totals (m2) & $\begin{array}{l}\text { Footprint } \\
\text { res. cons. }\end{array}$ & $\begin{array}{l}\text { Footprint } \\
\text { energy }\end{array}$ & $\begin{array}{l}\text { Ecological } \\
\text { Footprint PC }\end{array}$ \\
\hline Control Unit & $6.87 \mathrm{E}-01$ & $6.99 \mathrm{E}+02$ & \\
\hline Monitor & $5.79 \mathrm{E}-01$ & $1.07 \mathrm{E}+03$ \\
\cline { 1 - 2 } Keyboard & $3.27 \mathrm{E}-02$ & $7.11 \mathrm{E}+00$ \\
\hline Total & $1.30 \mathrm{E}+00$ & $1.77 \mathrm{E}+03$ & \multirow{2}{*}{0.18 ha } \\
\hline
\end{tabular}

Tab. 5. Results and EF of a PC

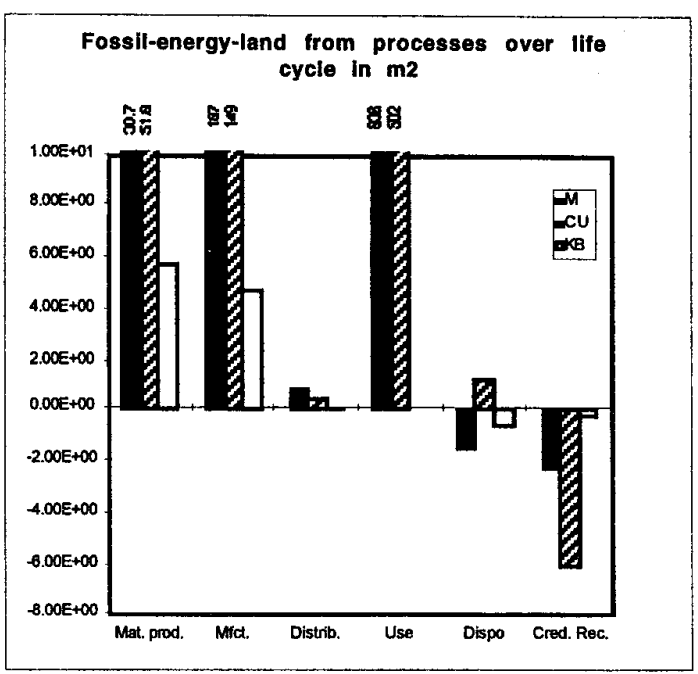

Fig. 3. Land-space from process energy.

Because $\mathrm{CO}_{2}$-emissions associated with nuclear energy are low, it is sometimes suggested as a solution to global warming. However, there are reasons to consider nuclear energy as unsustainable [14].

\section{Summary and Conclusions:}

In summary, a PC has a footprint of $1790 \mathrm{~m}^{2}$, or 0.18 ha over its lifetime of three years. It exceeds its own size by more than a thousandfold. A PC's footprint is almost exclusively determined by fossil fuel use. This is about 9 per cent of the EF of the world average citizen, and is assumed to be very high for a single product in relation to other activities people pursue, such as heating, lighting, driving. These 9 per cent do not account for other outputs from resource consumption.

The results reconfirm the use phase as the main culprit, followed by manufacturing and material production. However they account for only 25 and 9 per cent of the use phase. Due to energy efficiency measures, for example the US EPA Energy Star requirements, the footprint size could be reduced significantly. 
The results also show that small amounts of resources extracted can have a high consumption of land space, which was based on relatively high materials energy in the material production phase. However, this is offset by process energy in the use and manufacturing phase.

On the basis of the factors included in this study, the footprint from the resource consumption of raw materials appears to be negligible in comparison to the footprint from energy consumption. However, calculations suggest that at least $57 \times 10^{9}$ tonnes of material are dug from the earth's surface per year, of which $19.7 \times 10^{9}$ tonnes are minerals which are used, and $37.5 \times 10^{9}$ tonnes of which are waste or overburden. Apart from the energy associated with these material flows they also cause significant environmental site and off-site impacts $[18,19]$. At present, post-extraction data could only be included for a few non-renewable resources. No land use data was found so far for elements such as Gold, Silver, Tin, Lead and Zinc. They are present in PCs and have high environmental rucksacks, which must be seen in context with the impacts from global material flows. The strikingly high amount of water consumed over the PC's life cycle (over 16 million litres) has not yet been appropriated into land area. This suggests that the footprint for resource consumption is significantly underestimated.

Although the EF methods applied on electronic equipment needs to be further developed and refined, it is very effective for giving an overview of a product's consumption in relation to a human's fair earth share. It is a flexible tool which helps visualise the resource consumption on a product level (bottom up approach) through links with the global level (topdown approach) by comparison with the world average space per capita. As such, it is a holistic, dynamic instrument for planning sustainability which holds the potential for measuring space-efficient technology. The EF methodology does not compete with other assessment tools but should be seen complementary. However, due to its single indicator it is also unique in making for example LCA results visible and comparable on a global share basis. With further information available, footprint data could also be implemented into standard LCA software. With the establishment of EF for other products, more comparisons will be possible. The above findings suggest that EF are a suitable tool to be incorporated into IPP.

\section{Acknowledgements}

Special thanks to Prof. Lillemor Lewan from Lund University, Sweden, for her kind support in obtaining data for the footprint calculation, to Diana Deumling from Redefining Progress, San Francisco, and to Dr. Nigel Lawson, University of Manchester, $\mathrm{UK}$, for kindly providing information.

\section{References:}

[1] DIRECTORATE-GENERAL XI $\begin{aligned} & \text { (1998). Workshop on } \\ & \text { Integrated } \\ & \text { http://europa.eu,int/comm/environment/ipp/home.htm }\end{aligned}$

[2] BERKHOUT, F., SMITH, D., JOHNSON, E. (1998). Products and the environment: An integrated approach to policy. In: 3rd International Conference towards sustainable product design, London, 26-27 October 1998

[3] CHARTER, M. (1999). ETMUEL Workshop on 30 September 1999, Farnham, UK.

[4] SPRU (1998). EUROPEAN COMMISSION: DGXI integrated product policy. Final report.

[5] BUITENKAMP, M., SPAPENS, P. (1999). Ecospace Audit. An input analysis for products Amsterdam:Vereniging Milieudefensie.

[6] WACKERNAGEL,M., REES, W. (1996). Our ecological footprint. Reducing human impact on earth. Gabriola Island: New Society Publishers.

[7] WACKERNAGEL, M., LEWAN, L., HANSSON, C. (1999).Evaluating the use of natural capital with the ecological footprint. Paper in print.

[8] WACKERNAGEL, M. et al. (1997). Ecological footprints of nations. Study for the Rio +5 Forum. Universidad Anahueca de Xalapa, Mexico.

[9] LEWAN, L., WACKERNAGEL, M. (1998). The ecological footprint and biocapacity of Sweden. In: ConAccount Workshop. Amsterdam, 21 Nov. 62-68.

[10] ATLANTIC CONSULTING; IPU. Technical University of Denmark (1998). LCA Report: EU Ecolabel for Personal Computers. Third report in the study of the product group Peronal Computers in the EU Ecolabel scheme for DGXI of the European Commission.

[11] FRISCHKNECHT, R.. et al. (1996). Environmental life-cycle inventories for energy systems. Institute for Energy Technology ETHZ. Z, rich (in German).

[12] SCHMIDT-BLEEK, F., BRINGEZU, S. (1994). The use of mineral resources and sustainable development. In: Britisch Geological Survey Workshop, Chateau de Bellinglise, 5-7 May 1994.

[13] DOUGLAS, I., LAWSON, N. (1998). Problems associated with establishing reliable estimates of material flows linked to extractive idustries. In: ConAccount Workshop. Amsterdam, 21 Nov. 62-68.

[14] SCHMIDT-BLEEK, F. (1997). Wieviel Umwelt braucht der Mensch? Munchen: DTV. 
[15] IPCC (1997a). National Greenhouse Gas Inventories: Workbook. Revised 1996 Guidelines. Volume2. International Panel on Climate Change. http://ipccddc.cru.uea.ac.uk/index.html

[16] IPCC (1997b). National Greenhouse Gas Inventories:Reference Manual. Revised 1996 Guidelines. Volume2. International Panel on Climate Change. http://ipccddc.cru.uea.ac.uk/index.html.

[17] NISBET, E.G. (1991). Leaving Eden. To protect and manage the earth. Cambridge: Cambridge University Press.

[18] DOUGLAS, 1., LAWSON, N. (1999). The contribution of small-scale and informal mining to disturbance of the earth's surface by mineral extraction. Paper in print. School of Geography, The University of Manchester.

[19] SPANGENBERG, J.H. (1995). Towards sustainable Europe. Study on behalf of Friends of the Earth Europe. Wuppertal Institut .Wuppertal Papers No. 42 (in German).

[20] FISCHEDICK M. et al. Kernenergie: Rettung aus der drohenden Klimakatastrophe ofer Hemmschuh für effektiven Klimaschutz? Wuppertal Institut. Wuppertal Papers No. 55 (in German).

[21] MC LAREN, BULLOCK, S., YOUSUF, N. (1998). Tomorrow's world. London: Earthscan.

[22] WORLDBANK (1994). Environmental assessment Sourcebook Volum e3. Guidelines for environmental Assessment of energy and industry projects by World Bank Development Department. Worldbank Technical Paper 154, 83-89.

[23] DTI; SCOTTISH OFFICE (1995). The prospects of nuclear power in the UK. London: HMSO.

1 These are for example problems and risks associated with uranium production from uranium-ore processing and reprocessing, and unsolved problems with the long-term storage of radioactive waste $[20,1121]$. There are also political and economic objectives such as the global implication of nuclear energy with military use [21] and high capital and operation costs $[22,23]$. Other studies show that a focus on nuclear energy inhibits the development of more sustainable energy sources [11]. Wackernagel et al. assume that nuclear energy has the same footprint as fossil energy: rough calculations suggest that the lost ecological bio-production caused by the Chernobyl accident compared to the total nuclear power produced since the 1970 s leads to nuclear per [MJ] footprints larger than those of fossil fuel. As nuclear energy is not even economically competitive with fossil fuel, it will most likely be replaced in the short run with fossil fuel based energy [7]

If this

is taken into account, the EF of the PC would increase by about $160 \mathrm{~m}^{2}$, assuming a 12 per cent share of nuclear in an average European energy mix. 